\title{
PENGARUH MODEL PEMBELAJARAN CONTEXTUAL TEACHING LEARNING (CTL) TERHADAP HASIL BELAJAR SISWA PADA MATERI SUHU DAN KALOR
}

\author{
Addaini $^{1^{*}, \text { Sirry Alvina }}{ }^{2}$ \\ Mahasiswa $^{1}$,Dosen ${ }^{2}$ Program Studi Pendidikan Fakultas Teknik, Universitas Malikussaleh \\ KKorespondensi: dainipf.@gmail.com
}

\begin{abstract}
ABSTRAK: Tujuan penelitian ini untuk mengetahui pengaruh model pembelajaran Contextual Teaching Learning terhadap hasil belajar siswa pada materi suhu dan kalor di kelas XI SMA Negeri 1 Makmur. Jenis penelitian yang digunakan adalah Quasi Experimental Design dengan desain Nonequivalent Control Group Design, penelitian dilakukan di SMA Negeri 1 Makmur,. Pengumpulan data menggunakan instrument berupa tes yaitu tes awal (pretest) dan tes akhir (posttest), dan angket pada pembelajaran fisika. Data yang diperoleh dari hasil tes digunakan untuk menguji hipotesis penelitian dengan menggunakan Uji independent sample t-test. Dari hasil analisa diperoleh sig (2-tailed) = 0,000 dan dengan $\alpha=0,05$ yang berarti sig (2-tailed) $0,000 \leq \alpha=0,05$. Hal ini menunjukkan bahwa $\mathrm{H}_{1}$ diterima artinya terdapat pengaruh model pembelajaran Contextual Teaching Learning terhadap hasil belajar siswa pada materi suhu dan kalor. Hasil perhitungan setiap pertanyaan angket respon siswa diperoleh persentase $87,3 \%$ siswa sangat setuju dengan model pembelajaran Contextual Teaching Learning.
\end{abstract}

Kata kunci: Contextual Teaching Learning, Hasil Belajar.

\section{EFFECT OF CONTEXTUAL TEACHING LEARNING (CTL) LEARNING MODEL ON STUDENT LEARNING OUTCOMES IN TEMPERATURE AND CALOR}

ABSTRACT: This study aims to determine the effect of the Contextual Teaching Learning learning model on student learning outcomes in the temperature and heat material in class XI of SMA Negeri 1 Makmur. This type of research is Quasi Experimental Design. Data collection was carried out using instruments in the form of tests, namely pretest and posttest, and a questionnaire on physics learning. Data obtained from the test results are used to test the research hypothesis using the independent sample t-test. From the analysis results obtained sig (2-tailed) $=0,000$ and with $\alpha=0.05$ which means sig (2-tailed) $0,000 \leq \alpha=$ 0.05. This shows that H1 is accepted, it means that there is an influence of the Contextual Teaching Learning learning model on student learning outcomes in the material temperature and heat. The calculation results of each student questionnaire response obtained 87,3\% percentage, it can be concluded that the average response of students to the Contextual Teaching Learning model shows the category of very much agree.

Keywords: Contextual Teaching Learning, Learning Outcomes.

\section{PENDAHULUAN}

Pendidikan telah menjadi kebutuhan bagi setiap orang karena pendidikan memiliki peran penting dalam menciptakan sumber daya manusia yang berkualitas. Semakin tinggi tingkat pendidikan seseorang, semakin luas pula pola pikir dan tingkah lakunya. Pendidikan dijadikan sebagai tolak ukur seseorang mengenai cara berfikirnya, guna meningkatkan 
kesejahteraan dan mempertahankan hidup untuk menghadapi arus globalisasi. Menurut Peraturan Menteri Pendidikan Nasional Nomor 41 Tahun 2007, visi pendidikan nasional adalah terwujudnya sistem pendidikan sebagai pranata sosial yang kuat dan berwibawa untuk memberdayakan semua warga negara Indonesia agar berkembang menjadi manusia yang berkualitas sehingga mampu dan proaktif menjawab tantangan zaman yang selalu berubah (Sulistyaningsih Ratu Wangi, 2015).

Trianto (2010) menyatakan bahwa Ilmu Pengetahuan Alam (IPA) adalah pengetahuan yang diperoleh melalui pengumpulan data dengan eksperimen dan pengamatan untuk menghasilkan suatu penjelasan tentang sebuah gejala yang dapat dipercaya. Suparwoto (2011) mengemukakan bahwa pada hakikatnya IPA terdiri dari tiga komponen, yaitu sikap ilmiah, proses ilmiah, dan produk ilmiah. Fisika merupakan salah satu cabang dari Ilmu Pengetahuan Alam (IPA) yang mendasari perkembangan teknologi dan konsep hidup harmonis dengan alam. Perkembangan pesat pada bidang teknologi informasi dan komunikasi dewasa ini dipicu oleh temuan di bidang Fisika material melalui penemuan piranti mikro-elektronika yang mampu memuat banyak informasi dengan ukuran sangat kecil. Sebagai ilmu yang mempelajari fenomena alam, Fisika juga memberikan pelajaran yang baik kepada manusia untuk hidup selaras berdasarkan hukum alam. Pengelolaan sumber daya alam dan lingkungan serta pengurangan dampak bencana alam tidak akan berjalan secara optimal tanpa pemahaman yang baik tentang Fisika, Permendiknas No. 23 Tahun 2006: 502 (dalam Eko Mulyadi, 2015). Ilmu Fisika membantu kita untuk menguak dan memahami tabir misteri alam semesta ini. (Murtiani, dkk, 2012). Oleh karena itu fisika dipandang penting untuk diajarkan sebagai mata pelajaran pada jenjang SMA.

Berdasarkan observasi wawancara dengan guru dan siswa, dapat disimpulkan masalah bahwa hasil belajar siswa yang belum optimal khususnya pada materi suhu dan kalor yang disebabkan oleh guru yang masih menggunakan model Direct Instruction (DI). Trianto (2009) menyatakan bahwa Direct Instruction (DI) merupakan pembelajaran yang menekankan kepada proses penyampaian materi secara verbal dari seorang guru kepada siswa. Guru tidak mengaitkan konsep dengan kehidupan sehari-hari. Untuk itu guru harus bekerja keras dalam menentukan model pembelajaran yang sesuai dengan karakter materi yang diajarkan.

Salah satu model yang memiliki landasan filosofi kontruktivisme adalah model pembelajaran Contextual Teaching Learning (CTL). Menurut Sanjaya (dalam Sulistyaningsih Ratu Wangi, 2015), CTL memandang bahwa belajar bukan menghafal, akan tetapi proses berpengalaman dalam kehidupan nyata. Dengan pembelajaran kontekstual, proses pembelajaran diharapkan dapat berlangsung secara alamiah dalam bentuk kegiatan siswa untuk bekerja dan mengalami, bukan hanya transfer ilmu pengetahuan dari guru ke siswa, sehingga hasil pembelajaran dapat lebih bermakna bagi siswa. Berdasarkan uraian di atas maka peneliti tertarik untuk melakukan penelitian dengan judul "Pengaruh Model Pembelajaran Contextual Teaching Learning (CTL) Terhadap Hasil Belajar Siswa Pada Materi Suhu Dan Kalor Di Kelas XI SMA Negeri 1 Makmur".

Model pembelajaran kontekstual (Contextual Teaching Learning/CTL) merupakan konsep belajar yang membantu guru mengaitkan antara materi yang diajarkan dengan situasi dunia nyata siswa dan mendorong siswa membuat hubungan antara pengetahuan yang dimiliki dengan penerapan dalam kehidupan mereka sebagai anggota keluarga dan masyarakat. Kelebihan model pembelajaran ini yaitu hasil pembelajaran diharapkan alamiah dalam bentuk kegiatan siswa bekerja dan mengalami, bukan transfer pengetahuan dari guru ke siswa. Dengan konsep 
tersebut guru tidak hanya sekedar memberikan informasi tetapi lebih banyak berurusan dengan strategi untuk membantu siswa mencapai tujuannya (Abdi, 2011).

Menurut Sihono (2004) dalam jurnalnya, pengetahuan dibangun oleh manusia sedikit demi sedikit, yang hasilnya diperluas melalui konteks yang terbatas (sempit), dan tidak sekonyong-konyong. Pengetahuan bukanlah seperangkat fakta-fakta, konsep, atau kaidah yang siap untuk diambil dan diingat. Manusia harus mengkonstruksi pengetahuan itu dan memberi makna melalui pengalaman nyata. Filosofi inilah yang mendasari pengembangan model pembelajaran kontekstual (Contextual Teaching Learning/CTL).

Anggriani, Retno, Ariani, \& Sukardjo, (2012), dalam jurnalnya menyatakan bahwa "Belajar akan lebih bermakna jika siswa mengalami apa yang dipelajarinya, bukan hanya sekedar mengetahuinya". Sedangkan Johnson (dalam Rusyida, Asikin, \& Soedjoko, 2013) menyatakan bahwa model pembelajaran Contextual Teaching Learning (CTL) merupakan sebuah sistem yang merangsang otak untuk menyusun pola-pola sehingga menghasilkan makna dengan menghubungkan muatan akademis dengan konteks dari kehidupan sehari-hari siswa.

Menurut Idrus Hasibuan (2014), langkah-langkah model pembelajaran CTL adalah sebagai berikut :

1. Mengembangkan pemikiran bahwa anak akan belajar lebih bermakna dengan cara bekerja sendiri, menemukan sendiri, dan mengkonstruksi sendiri pengetahuan dan keterampilan barunya.

2. Melaksanakan sejauh mungkin kegiatan inquiri untuk semua topik.

3. Mengembangkan sifat ingin tahu siswa dengan bertanya.

4. Menciptakan masyarakat belajar.

5. Menghadirkan model sebagai contoh belajar.

6. Melakukan refleksi diakhir pertemuan.

7. Melakukan penilaian yang sebenarnya dengan berbagai cara.

Menurut Yatim Riyanto (dalam Aji, 2015), belajar adalah suatu proses mengonstruksi pengetahuan dan memberi makna melalui pengalaman nyata. Pengetahuan dibangun oleh manusia sedikit demi sedikit. Hasilnya diperluas melalui konteks yang terbatas dan tidak seketika, artinya dalam belajar dibutuhkan suatu proses. Senada dengan hal tersebut Muhammad Thobroni (dalam Aji, 2015) menyatakan bahwa belajar dibangun atas pengalaman-pengalaman sendiri. Manusia untuk belajar menemukan sendiri kompetensi, pengetahuan atau teknologi dan hal lain yang diperlukan guna mengembangkan dirinya.

Menurut Reza (2015) hasil belajar merupakan hal yang berhubungan dengan kegiatan belajar karena kegiatan belajar merupakan proses sedangkan hasil belajar adalah sebagian hasil yang dicapai seseorang setelah mengalami proses belajar dengan terlebih dahulu mengadakan evaluasi dari proses belajar yang dilakukan. Sedangkan menurut Jihad dan Haris (2012) hasil belajar merupakan pencapaian bentuk perubahan perilaku yang cenderung menetap dari ranah kognitif, afektif, dan psikomotorik dari proses belajar yang dilakukan dalam waktu tertentu.

\section{METODE}

Metode penelitian yang digunakan dalam penelitian ini adalah Quasi Experimental Design. Peneliti memilih Quasi Experimental Design dalam bentuk Nonequivalent Control Group Design. Dalam desain ini terdapat dua kelompok yang dipilih secara purposive, kemudian diberi pretest untuk mengetahui keadaan awal adakah perbedaan antara kelompok eksperimen dan kelompok kontrol. 
Populasi dari penelitian ini adalah seluruh siswa kelas XI SMA Negeri 1 Makmur terdiri dari 3 kelas yang berjumlah 63 orang pada materi suhu dan kalor tahun pelajaran 2019/2020. Adapun teknik pengambilan sampel dipilih secara sampling purposive, yaitu teknik penentuan sampel dengan pertimbangan tertentu (Sugiyono, 2017). Sampel diambil secara purposive karena berdasarkan arahan dari guru mata pelajaran fisika di sekolah tersebut. Maka yang menjadi sampel penelitian ini adalah siswa kelas XI MIA2 yang berjumlah 21 siswa sebagai kelas eksperimen dengan model pembelajaran Constextual Teaching Learning dan kelas XI MIA1 yang berjumlah 21 siswa sebagai kelas kontrol dengan model pembelajaran Direct Instruction (DI).

Alat pengumpul data dalam penelitian ini adalah berupa test awal dan test akhir materi pembelajaran yang diberikan kepada siswa. Bentuk test yang diberikan yaitu berupa pilihan berganda yang terdiri dari lima pilihan jawaban dengan jumlah soal 15 butir. Sebelum tes digunakan terlebih dahulu dicari validitas, dengan menggunakan validitas isi, yang divalidkan oleh orang yang ahli dibidangnya (validator). Dalam penelitian ini peneliti menggunakan angket respon siswa sebagai instrument nontes. Angket siswa berisi pertanyaan berjumlah 20 pertanyaan yang berkaitan dengan proses pembelajaran siswa. Angket siswa digunakan untuk mengetahui keadaan awal siswa atau masalah yang dihadapi siswa saat belajar. Peneliti menyebarkan angket kepada 21 siswa di kelas eksperimen. Setelah memperoleh skor Pretest dan Posttest dari kedua kelas, maka data tersebut akan dilanjutkan ke uji hipotesis (uji-t). Adapun syarat untuk uji-t harus memenuhi uji normalitas dan uji homogenitas, apabila kedua data telah normalitas dan homogenitas, maka akan dilanjutkan ke uji hipotesis (uji-t).

\section{HASIL DAN PEMBAHASAN}

Berdasarkan penelitian yang telah dilakukan, hasil belajar siswa diperoleh dari data pretest dan posttest. Adapun data pretest dan posttest dapat dilihat pada Tabel berikut:

Tabel 1. Data Hasil Pretest-Posstest Kelas Eksperimen dan Kelas Kontrol

\begin{tabular}{ccccl}
\hline Hasil & N & Min & Max & Mean \\
\hline Pretest eskperimen & 21 & 27 & 53 & 56 \\
Posttest eksperimen & 21 & 53 & 73 & 86 \\
Pretest kontrol & 21 & 27 & 53 & 52 \\
Posttest kontrol & 21 & 40 & 60 & 66 \\
\hline
\end{tabular}

Dari hasil tes belajar kelas eksperimen menggunakan model pembelajaran Contextual Teaching Learning diperoleh rata-rata data pretest dan posttest yaitu 56 dan 86, kelas kontrol menggunakan model pembelajaran Direct Intruction (DI) diperoleh rata-rata pretest dan posttest yaitu 52 dan 66. Untuk melihat perbedaan rata-rata kelas eksperimen dan kelas kontrol dapat dilihat pada Gambar dibawah ini: 


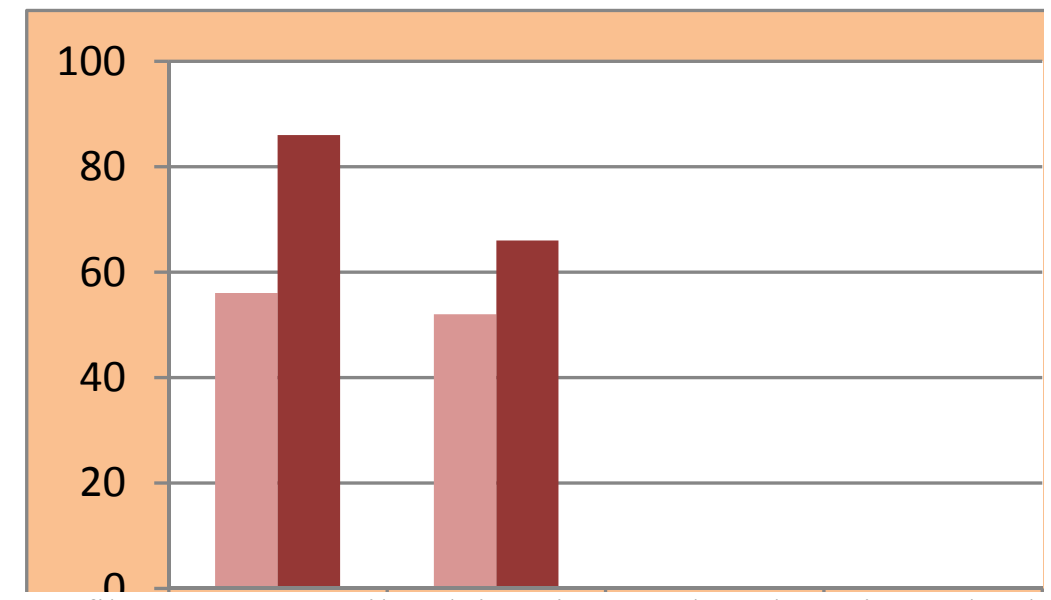

Gambar 1. Grafik Rata-rata Hasil Belajar Siswa Kelas Eksperimen dan kelas Kontrol

Berdasarkan angket respon peserta didik yang diisi oleh 21 peserta didik di kelas XI MIA2 yang diajarkan menggunakan model pembelajaran Contextual Teaching Learning. Hasil perhitungan persentase keseluruhan respon peserta didik dengan menggunakan model Contextual Teaching Learning dapat dilihat pada tabel berikut:

Tabel 2. Hasil perhitungan keseluruhan respon siswa

\begin{tabular}{c|c|c}
\hline No & Respon siswa & Persentase (\%) \\
\hline 1 & Sangat setuju & 70 \\
2 & Setuju & 16 \\
3 & Tidak setuju & 7 \\
4 & Sangat tidak & 7 \\
& setuju & \\
\hline & Jumlah & 100 \\
\hline
\end{tabular}

Adapun hasil perhitungan untuk setiap pernyataan angket respon siswa dengan menggunakan model pembelajaran Contextual Teaching Learning dapat di lihat pada tabel berikut ini :

Tabel 3. Hasil perhitungan untuk setiap aspek dari pernyataan angket respon siswa

\begin{tabular}{lcc}
\hline \multicolumn{1}{c}{ Aspek } & No item & $\begin{array}{c}\text { Rata-rata Pesentase } \\
(\%)\end{array}$ \\
\hline Pembelajaran dengan diskusi kelompok & $5,15,17$ & 92 \\
Berperan aktif dalam kegiatan pembelajaran & $3,6,8,10,11$, & 87 \\
Pembelajaran dengan model Contextual Teaching & 18 & 86 \\
Learning & $1,4,9,19,20$ & 86 \\
Kegiatan/proses pembelajaran & $2,7,12,13,14$, & 8 \\
\hline
\end{tabular}


Berdasarkan hasil Uji Independent Samples Test pada bagian Equal variances assumed diketahui nilai signifikan sebesar $0,000<0,05$, maka dengan demikian sesuai dengan dasar pengambilan keputusan dalam Independent Samples Test dapat disimpulkan bahwa $\mathrm{H}_{0}$ ditolak dan $\mathrm{H}_{1}$ diterima. Artinya bahwa ada pengaruh model pembelajaran Contextual Teaching Learning terhadap hasil belajar siswa pada materi suhu dan kalor di kelas XI SMA Negeri 1 Makmur.

Model pembelajaran Contextual Teaching Learning dapat meningkatkan hasil belajar siswa karena siswa bekerja dan mengalami, bukan hanya transfer ilmu pengetahuan dari guru ke siswa, sehingga hasil pembelajaran dapat lebih bermakna bagi siswa. Model pembelajaran Contextual Teaching Learning berpengaruh terhadap hasil belajar siswa pada materi suhu dan kalor juga disebabkan oleh proses pembelajaran yang menghadapkan siswa pada sebuah kasus, pertanyaan, dan siswa harus melakukan percobaan untuk menemukan materi yang dipelajari, percobaan dilakukan dengan menggunakan alat dan bahan yang dapat ditemui siswa dalam kehidupan sehari-hari, kegiatan ini membuat siswa aktif dan tertarik mencari jawaban melalui percobaan. Menurut Anggriani, Retno, Ariani, \& Sukardjo, (2012), dalam jurnalnya menyatakan bahwa "Belajar akan lebih bermakna jika siswa mengalami apa yang dipelajarinya, bukan hanya sekedar mengetahuinya". Sedangkan Johnson (dalam Rusyida, Asikin, \& Soedjoko, 2013) menyatakan bahwa model pembelajaran Contextual Teaching Learning (CTL) merupakan sebuah sistem yang merangsang otak untuk menyusun pola-pola sehingga menghasilkan makna dengan menghubungkan muatan akademis dengan konteks dari kehidupan sehari-hari siswa.

\section{PENUTUP}

Berdasarkan hasil penelitian dan analisis data peneliti dapat menyimpulkan bahwa: Hasil analisis uji-t diketahui nilai sinifikan sebesar $0,000<0,05$, maka dengan demikian sesuai dengan dasar pengambilan keputusan dalam Independent Samples Test dapat disimpulkan bahwa $\mathrm{H}_{0}$ ditolak dan $\mathrm{H}_{1}$ diterima. Artinya bahwa ada pengaruh model pembelajaran Contextual Teaching Learning terhadap hasil belajar siswa pada materi suhu dan kalor di kelas XI SMA Negeri 1 Makmur. Respon peserta didik terhadap model pembelajaran Contextual Teaching Learning diperoleh persentase $87.3 \%$ maka dapat disimpulkan bahwa rata-rata respon peserta didik terhadap model pembelajaran Contextual Teaching Learning ini menunjukkan kategori sangat setuju.

\section{DAFTAR PUSTAKA}

Abdi, M. I. (2011). Contextual Teaching and Learning (CTL) dalam Pembelajaran PAI. Dinamika Ilmu, 11(1).

Anggriani, W., Retno, S., Ariani, D., \& Sukardjo, J.( 2012). Pengaruh Pembelajaran Kimia Dengan Pendekatan Ctl (Contextual Teaching Learning) Melalui Metode Eksperimen Dan Proyek Terhadap Siswa Pada Materi Destilasi Kelas X Smk Negeri 2 Sukoharjo Tahun Ajaran 201 /2012. JPK, Jurnal Pendidikan Kimia, 1(1), 80-88.

Hasibuan, Idrus. (2014). Model Pembelajaran CTL (Contextual Teaching Learning). Jurnal Logaritma, 2(1). 
Jihad, A. dan Abdul Haris, (2012). Evaluasi pembelajaran. Yogyakarta: Multi Presindo.

Murtiani, Fauzan, A, \& Wulan, R, (2012). Penerapan Pendekatan Contextual Teaching Learning (Ctl) Berbasis Lesson Study Dalam Meningkatkan Kualitas Pembelajaran Fisika Di Smp Negeri Kota Padan. Jurnal Penelitian Pendidikan Fisika, 1(2012), 1-21.

Putra, P. A. (2015). Meningkatkan Hasil Belajar Matematika Siswa Kelas Viii Smp Pgri Arjosari Tahun Pelajaran 2013/2014 Melalui Implementasi Pembelajaran Teknik Jigsaw. Jurnal Pendidikan Matematika, 1(2), 33-42.

Rachmadtullah, Reza. 2015. Kemampuan Berfikir Kritis Dan Konsep Diri Dengan Hasil Belajar Pendidikan Kewarganegaraan Siswa Kelas $V$ Sekolah Dasar. Jurnal Pendidikan Dasar. 6(2).

Rusyida, W. Y., Asikin, M., \& Soedjoko, E. (2013). Komparasi Model Pembelajaran CTL dan MEA terhadap Kemampuan Pemecahan Masalah Materi Lingkaran.Unnes Journal of Mathematics Education, 2(1), 1-7.

Sihono, T. (2004). Contextual Teaching Learning (Ctl) Sebagai Model Pembelajaran Ekonomi Dalam Kbk. Jurnal Ekonomi Dan Pendidikan, 1(1), 63-83.

Sugiyono, (2017). Metode Penelitian Pendidikan Pendekatan Kuantitatif, Kualitatif, Dan $R \& D$. Bandung: ALFABETA, cv.

Suparwoto. (2011). Sains dan Kajian Filsafat. Yogyakarta: FMIPA UNY.

Trianto. (2009). Mendesain model pembelajaran inovatif-progresif. Jakarta: Kencana.

Trianto. (2010). Model Pembelajaran terpadu. Jakarta: Bumi Aksara.

Wangi, Ratu, Sulistyaningsih. (2015). Penerapan Model Pembelajaran Ctl Dengan Strategi React Untuk Meningkatkan Hasil Belajar Dan Kedisiplinan Siswa Pada Materi Geometri. Skripsi tidak diterbitkan. Semarang: Universitas Negeri Semarang. 